\title{
Influence of Teacher's Competence on Students Learning in Some Selected Secondary Schools in Buea Municipality in the South West Region of Cameroon
}

\section{Awandia Joseph Tazitabong, Ph.D}

Lecturer, Department of Curriculum Studies and Teaching, Faculty of Education, University of Buea, Cameroon

DOI - http://doi.org/10.37502/IJSMR.2021.4809

\begin{abstract}
This study examined "The Influence of Teacher's Competence on Students' Learning in Some Selected Secondary Schools in Buea Municipality. Four research questions were formulated to guide the study. The study adopted a survey research design. The target population of the study consisted of 5,992 students, drawn from six secondary schools that where selected using stratified sampling technique. The accessible population consisted of 703 form four students drawn from the six schools. The sample size was made up of 300 students. This sample size was obtained using simple random sampling technique. A closed ended four-point Likert scale questionnaire was used for data collection. To ensure reliability of the questionnaire, the instrument was pilot tested in a school not included in the study. Their responses were subjected to Cronbach's Alpha Coefficient reliability test which yield a value of 0.713 . The data was analysed using Pearson product moment correlation coefficient. The findings revealed that there exists a significant positive relationship between teachers professional, pedagogic, socio-emotional, personality competence and students' learning in secondary schools in Buea Municipality. Based on the findings, the following recommendations were proffered; teachers should partake in seminars/workshops if possible, because this will improve their teaching competence; educational administrators should equip the regional pedagogic inspectors with sufficient pedagogic didactic materials that they can use to train or carry out in-service training for the teachers doing seminars/workshops, principals should encourage mentor-mentee relationship among teachers of the same department, because this will help train the novice teachers on all the aspects of competence and this will intend booze their self-esteem. And lastly, the decision-makers should recruit more trained teachers so as to reduce teacher-student ratio. This is very important because, teacher competence can only be effective in a classroom that meets international standard of teacher-student ratio.
\end{abstract}

Keywords: Teacher's professional competence, pedagogic competence, social-emotional competence, personality competence and students learning. 


\section{Introduction}

It is widely accepted that Education is a master key to rapid social, economic and political development of a nation. Thus, it is a sure process of developing the citizenry cognitively, affectively and psychomotively Julkifli (2016). The teacher is the pivot above which the educational process rests. In fact, no educational system can rise beyond the quality of its teachers. This underscores the need for adequate training and constant skill development for our teachers. Teaching is a process of transferring knowledge from the teacher to the learner for the sake of changing behaviour and skill acquisition. Teaching is considered as a noble profession and the teachers are always called nation builders. That is why teaching as a profession, is a body of knowledge, a set of attitudes, codes of ethics and a technique which is applied to the service of mankind through an educated group. There is a code of conduct or behaviour which serves as guidelines to help teachers perform their functions credibly so as to achieve the predetermine goals of the school.

Being a teacher is not as easy as the people think, because "teachers play an important role in what they do, and how they do in developing their own professional knowledge and practice and thus become the models for their students (Livia, 2010: 1). Thus, the teacher's attitude and behavior would most likely be imitated by their students in the class. In other words, a teacher also carries a big responsibility in her classroom. One reason is that the teachers are people who are very influential in teaching-learning process. Everything they say would have an impact on their students. If the teacher feels happy or angry, it would be spread among students because their attitude would get contagious to students. Therefore, teachers should really bring their students to the objectives to be achieved because all students depend on them.

Having a good teacher is absolutely demanded by the students themselves, because good teachers can help them to develop and encourage effective learning. A good teacher should have an adequate teaching knowledge and skills; they also should master the subject matter that would be taught to their students. Additionally, a good teacher is the most determinant of the student's achievement in the classroom (Hayes, 2003: 54). So, the achievement of the students is seen from how the teachers master all the abilities of teaching. Thus, having basic skills is one of the most essential aspects for becoming good teachers. It can help them to develop and elaborate the courses and methods explicitly. Besides that, the teachers are required to be more progressive than students and they should also have more knowledge about things that they would explain to their students (Livia, 2010: 1).

Mulyasa (2007) stated that competence is knowledge, skills, and abilities or capabilities that a person achieves, which become part of his or her being to the extent he or she can satisfactorily perform particular cognitive, affective, and psychomotor behaviours. So, the competence is knowledge, skills and behavior that enable someone to do something well. In addition, Slavík (2008) defined the teacher competence as a set of knowledge, skills and teachers' personal qualities. The teaching competency is associated with the complex combination of knowledge, skills, and abilities to have professional performance in the classroom as an educator. 
According to Usman (1994), competence is "the one thing that describes a person's qualifications or ability both qualitatively and quantitatively". This notion implies that the competence can be used in two contexts, namely: firstly, as an indicator of ability that shows the acts observed; secondly, as a concept that includes aspects of cognitive, effective and acts as well as the stages of implementation as a whole. In the other hand, competence is an underlying characteristic of an individual that is causally related to criterion-referenced effective and/or superior performance in a job or situation. Underlying characteristics means the competency is a fairly deep and enduring part of a person's personality and can predict behavior in a wide variety of situations and tasks. Causally related means that a competency causes or predict behavior and performance. Criterion referenced means that the competency actually predicts who does something well or poorly, as measured on a specific criterion or standard (Spencer and Spencer, 1993:9).

Competencies are defined as "the set of knowledge, skills, and experience necessary for the future, which manifests in activities" (Katane et. al. 2006). Gupta (199) define competencies as "knowledge, skills, attitudes, values, motivations and beliefs people need in order to be successful in a job." Teachers as one component in the learning process play a role in the formation of human resources business potential in development. In this framework, teachers are not just teaching the transfer of knowledge, but also as an educator transfer of values as well as mentors who provide guidance and guiding students in learning (Sardiman, 2001) Teachers as educators, have an important role in the learning process, teachers have a duty and a great responsibility towards the sustainability of the learning process, which begins with the preparation of lesson plans, implement learning activities, evaluating, analyzing the results of the evaluation, and follow up the results of learning.

Teacher competence is the teacher's ability to educate students in the teaching and learning process in order to create outstanding students based on the four competencies they have, namely; pedagogical, personal, professional, and social competence (Nnisa,2020). Teachers' competence development should result in improvements of teachers' actions and in students' achievement of learning goals. To support this, expertise should be used both about effective teachers' competence development and students' learning goals (Garet et al., 2001; Kuijpers, Houtveen, \& Wubbels, 2010; Timperley, Wilson, Barrar, \& Fung, 2007). Consensus is growing that for teacher professional development activities to be effective, the following features are important: content focus, active learning, coherence, duration and collective participation (Desimone, 2009; Garet et al., 2001; Penuel et al., 2007). The word 'content' in 'content focus' refers to the knowledge teachers should develop. This implies knowledge about what the students should learn, content knowledge) as well as knowledge about teaching actions needed to support students' learning that is, pedagogical content knowledge (Bransford et al., 2005). The word 'focus' means that a teacher development programme should concentrate on what the teachers have to develop, the core of which in this study is: giving feedback to support students' reflection. Competencies that must be acquired by teachers are: professional competence, personality, pedagogical, and social- emotional. Professional competence is the ability in mastering the materials to fulfill the standard base competency which has been set by the Minister of Education. A professional teacher is a person who has the ability and expertise in the field of teaching or in other words he is 
educated and well trained. Educated and trained not only gain formal education but also have to master a variety of strategies or in the techniques of teaching and learning activities and master the foundations as noted in the educational competence of teachers.

The focus of this study is to investigate the impact of teachers' competence (pedagogical, personal, professional, and socio-emotional competence) on students' learning in some selected secondary schools in Buea municipality.

\section{Statement of the Problem}

The main duty of the teacher is to facilitate the acquisition of knowledge, attitudes and skills. This demands that, a teacher needs to be confident and ethically sound. It is important that, apart from having knowledge of subject matter, teachers need to have a sense of discrimination between right and wrong and to fully observe the code of conduct in the teaching profession. It is a common knowledge that when teachers are seen upholding sound professional ethics, it creates a high level of public confidence and trust in the teaching profession. However, this seems not to be the case with some of today's teachers. From the researcher's observation there are concerns, complaints and comments from different stakeholders regarding the academic performance of learners in Cameroon in general and Buea municipality in particular. It seems that there is a mismatch between the expectations of parents regarding learner achievement and learners' actual performance and also, between teacher's performance and their actual competences expected by parents and other stakeholders. For example, many students in secondary schools cannot write and speak English well. Many cannot perform basic life skills expected of them to cope in the society while some manifest very poor moral or ethical behaviours such as fighting with their teachers and having sex in schools. Instead of students learning what is recommended in the school curriculum, they instead learn a lot of bad behaviours. It has also been observed that some teachers are so mean to the extent that they exchange marks for money and sex. The researcher thinks that, this public outcry, therefore, calls for an intensive investigation into teachers' compliance with teaching professional ethics (norms, values, principles and regulations). It is against this background that the researcher decided to investigate whether teachers' competence (pedagogical, personal, professional, and socioemotional competence) is a significant determinant of students' learning in secondary schools in the Buea municipality.

\section{Theoretical Review}

This study is guided by Kohlberg (1958) Theory of Moral Development and The Big Five Model by Piedmont and Weinstein (1994).

Kohlberg (1958), identified three distinct levels of moral reasoning, each with two sub stages. According to him, people can only pass through these levels in the order listed. Each new stage replaces the reasoning typical of the earlier stage and everyone achieves all the stages. To Kohlberg, moral development in human beings occurs over age and experience. Kohlberg suggested that there are three levels of moral development, namely pre-conventional, 
conventional, and post-conventional, based on the type of reasoning and motivation of the individuals in response to moral questions.

In the pre-conventional level, right conduct for an individual is regarded as whatever directly benefits oneself. At this level, individuals are motivated by obedience or the desire to avoid punishment or to satisfy their own needs or by the influence of power on them. This level is divided into two stages namely obedience and punishment orientation stage; which state that the child/individual is good in order to avoid being punished, if a person is punished, they must have done wrong and the individualism and exchange stage; which states that children recognize that there is not just one right view that is handed down by the authorities. Different individuals have different viewpoints.

At the conventional level, people respect the law and authority. Rules and norms of one's family or group or society are accepted, as the standard of morality. Individuals in this level want to please or satisfy, and get approval by others and to meet the expectations of the society, rather than their self-interest (e.g., good boy, good girl). Loyalty is regarded as most important. This level is also divided into two stages which include: good interpersonal relationships; where the child/individual is good in order to be seen as being a good person by others, and maintaining the social order; where the child/individual becomes aware of the wider rules of society so judgments concern obeying the rules in order to uphold the law and to avoid guilt. At the post-conventional level, people are called autonomous. They think originally and want to live by universally good principles and welfare of others. They have no self-interest. They live by principled conscience. They follow the golden rule: 'Do unto others as you would have them do unto you'. They maintain moral integrity, self-respect and respect for others. Individual judgment is based on self-chosen principles, and moral reasoning is based on individual rights and justice. This stage is equally divided into two stages: social contract and individual rights; where the child/individual becomes aware that while rules/laws might exist for the good of the greatest number, there are times when they will work against the interest of particular individuals and universal principles; where people have developed their own set of moral guidelines which may or may not fit the law. The principles apply to everyone. Kohlberg believed that individuals could only progress through these stages, one stage at a time. He believed that most of the moral development occurs through social interactions.

This theory has implication to this study in that; it is used to understand a range of leadership decisions teachers make in the teaching profession, ranging from the least ethical to the resoundingly ethical. What would a teacher take into consideration if he or she were at each stage of the moral development of Kohlberg before making a decision? What will be their professional conducts when they are taking moral decisions based on each stage of the moral development? Answers to these questions provide reasons to explain teachers' professional ethics which speaks to their competences, self-esteem, and relationship with students and other colleagues. In addition, the last level of moral judgment entails reasoning rooted in the ethical fairness principles from which moral laws would be devsed. Laws are evaluated in terms of their coherence with basic principles of fairness rather than upheld simply on the basis of their place within an existing social order. Thus, there is an understanding that 
elements of morality such as regard for life and human welfare transcend particular cultures and societies and are to be upheld irrespective of other conventions or normative obligations.

According to Piedmont and Weinstein big Five Model (1994), the five factors usually labeled neuroticism (the tendency to experience negative effect, such as anxiety, insecurity and psychological distress), extraversion (the quantity and intensity of interpersonal interaction and activity level), openness to experience (the proactive seeking and appreciation of new experiences), agreeableness (the quality of one's interpersonal interaction along a continuum from compassion to antagonism) and conscientiousness (the amount of persistence, organization and motivation in goal-directed behaviors).

Bozionelos (2004) stated extroversion is characterized by sociability, assertiveness, social dominance, ambition, tendencies towards action, sensation-seeking and the experience of positive affect. Based on Bozionelos (2004), agreeableness is associated with altruism, friendliness and modesty, while low agreeableness includes antagonism, impression management and selfishness.

Judge et. al (2002) mentioned conscientiousness focus on how people approach their work. People in high conscientiousness have sense of duty and obligation to their work and have high job performance, career success, motivation and job satisfaction. According to Bozionelos (2004), neuroticism encompasses characteristics that include excessive worry, pessimism, low confidence and tendencies to experience negative emotions.

According to Eysenck (1986), extraverts tend to seek interaction with others, novel experiences and complex, varied and intense stimuli, extroverts, on the other hand, prefer their own company and prefer the familiar and unfamiliar. While Costa and McCrae (1992) stated that extroverts are gregarious, assertive, activity and excitement-seeking. It similar with Mount and Barrick (1995) which mentioned that extraversion is most often described as the degree to which an individual is sociable, gregarious, talkative, assertive, adventurous, active, energetic and ambitious. Based on Watson and Clark (1997), extroverts have been found to be socially engaging, gregarious, assertive, expressive, articulate, comfortable in group settings and have a great number of friends. Williams (1997), extraverts also tend to be high in positive affectivity, self-efficacy and optimism. According to Harris and Fleming (2005), extroversion represents various aspects such as sociable, gregarious, assertive and talkative. However, Manning et. al (2006) stated that extroversion is about the extent to which people are comfortable in social relationships, how socially inhibited, and the extrovert who is comfortable in social relationships and socially uninhibited. Tallman and Bruning (2008) stated that extroverts' need for power and recognition may also cause them to take more risks in the job and they would expect the organization to support their work activities. Besides, Tallman and Bruning (2008) also stated people high in extroversion tend to be high performers and committed to the organization and their work. They will develop psychological contracts that reflect their hard work, commitment and willingness to work with others.

According to Costa and McCrae (1992), agreeableness is associated with "the need for intimacy", the recurrent preference in thought and behavior for experience of warm, close 
and communicative interactions with others. Individuals high in agreeableness are trusting, cooperative, altruistic, compliant and "moved by others". However, Graziano et. al (1996) mentioned that high agreeable individuals may in their pursuit of harmonious relations generate more positive attributions to otherwise provocative behavior than low-agreeable persons would do. Based on Barry and Friedman (1998), agreeableness is related to "prosocial motives", aimed at seeking good outcomes for oneself as well as for other group members. Judge et. al (2002) stated that agreeable individuals have greater motivation to achieve interpersonal intimacy. While, Harris and Fleming (2005) which mentioned that agreeableness describes the courteous, sympathetic, tender-hearted and kind characteristics. Dijkstra et. al (2005), those who are low in agreeableness have been described as antagonistic, competitive, cynical, callous, ruthless and cruel, and they tend to experience and express hostility. According to Manning et. al (2006), agreeableness is about the extent to which people are sensitive and responsive to others, including the extent to which they will defer to them. The two extremes are the tough-minded individual, operating predominantly at a thinking level and lacking sensitivity and responsiveness, and the tender-minded individual, operating predominantly at a feelings level and displaying sensitivity and responsiveness. Bernerth et. al (2007), agreeable individuals are described as good-natured, cheerful and caring. An individual high in agreeableness is fundamentally altruistic.

Barrick and Mount (1991) mentioned that conscientious individuals have been characterized as dependable, responsible, hard-working, self-disciplined, persistent, planful and organized. Similarly with Costa and McCrae (1992) which mentioned that conscientious people value duty, competence, self-discipline and achievement. Besides, Costa and McCrae (1992) also mentioned that conscientiousness consist of the specific traits of competence, order, dutifulness, achievement striving, self-discipline and deliberation. Based on Mount and Barrick (1995), individuals high in conscientiousness are characterized as being responsible, careful, preserving, orderly, cautious, planful, hardworking and achievement-oriented. As stated by Wright (2003), people high in conscientiousness have a sense of duty and obligation to their work and have high job performance, career success, motivation and job satisfaction. However, Harris and Fleming (2005) stated that conscientiousness refers to characteristics such as being organized, orderly, precise and efficient. Manning et. al (2006) stated that conscientiousness is about the number of goals that an individual pursues and the extend which they pursue them in a focused way. The two extremes are spontaneous individual, who pursues many goals but in an unfocused way and the conscientiousness individual, who pursues fewer goals but does so in a more focused, controlled and structured way

Neuroticism is always related to the characteristics of people who have negative affect and low in self-esteem. According to Watson and Clark (1984) negative affect is defined by a propensity to view the world in a negative emotional state. Similarly with Levin and Stokes (1989), which mentioned that individuals high in negative affect tend to focus on the negative aspects of other people and themselves. George (1996) also stated the same view which individuals high in negative affectivity, a concept related to the neuroticism are likely to be more pessimistic, taking a negative view of themselves and the world around them. While Brockner (1988) mentioned that persons low in self-esteem and self-efficacy look to others for approval. Turban and Dougherty (1994) mentioned that individuals with low self-esteem 
tend to withdraw from challenging situations, are less confident in their abilities, less likely to seek feedback, and see themselves as less appealing to others. Judge et. al (1998) mentioned that neuroticism has been found to be negatively related to self-esteem, self-efficacy and locus of control. Both of these characteristics are supported by Bernerth et. al (2007) as characteristic in neuroticism, which they mentioned that neuroticism is composed of several characteristics including low self-esteem and negative affectivity. However, Costa and McCrae (1992), neuroticism consists of the specific traits of anxiety, angry hostility, depression, self-consciousness, impulsiveness and vulnerability. Based on Mount and Barrick (1995), neuroticism as "emotional stability" (reverse scale) by some researchers and can be further conceptualized as the extent to which a person is emotional, insecure, nervous, fearful and apprehensive. Some researcher stated that neuroticism persons and also limited in social skills and are not interested in any long-term relationship. As stated by Judge et. al (1997), research has shown neurotic individuals are severely limited in their social skills. Raja et. al (2004) mentioned that the neurotic individuals are not likely to establish long-term relationships that demand commitments, social skills and trust in other.

According to Costa and McCrae (1992), openness to experience is related to active imagination, aesthetic sensitivity, attentiveness to inner feelings, preference for variety, intellectual curiosity, and independence of judgment. Costa and McCrae (1992) also stated that high openness employees seek challenging and interesting work and would expect the organization to satisfy this need. People who are open have a high need for autonomy and tend to be creative, adaptive and accepting of change. Similar with Judge and Bono (2000) which mentioned that open individuals are also at time better able to understand and adapt to new perspectives. Based on Bozionelos (2004), individuals who score high on openness should be more likely to report involvement in their work, as their work can serve as the arena to entertain their curiosity, their appetite for exploring new perspectives, and their tendency to develop genuine interests for any activities they are involved in. While, Harris and Fleming (2005) mentioned that openness to experience or creativity refers to personal characteristics such as being imaginative, original and curious. However, most of the researchers mentioned that openness is more on openness to the new experience or change. Manning et. al (2006) also stated the same perspective where they mentioned that openness is about a person's openness to new experience and is manifested in such things as an individual's breadth of interests, level of creativity and intellectual qualities. At two extremes are the conventional individual, who is relatively closed to new experiences and open individual, who is relatively open to such experiences.

\section{Review of Reletaed Literature}

According to Irwanto and Yusuf (2016) the pedagogic competence of teachers has several indicators, namely: (a) teachers understanding the characteristics of students, (b) teachers understanding learning theories and the principles of educational learning, (c) curriculum development, (d) educational learning activities, (e) developing potential students, (f) communication with students, and (g) assessment and evaluation.

Pedagogic competence is the main competence teachers must have in order to make learning effective and dynamic. Development of pedagogical competence is done by providing 
opportunities for teachers to improve their knowledge and skills to develop teaching materials and use various methods of learning in the learning process, provides the opportunity for teachers to take the initiative and creativity in working to develop insight knowledge (payu, 2011). Motivation of teachers tends to lack of instructional media. Achievement motivation must be supported by the principal to provide the opportunity for teachers to conduct research and perform a variety of activities aimed at improving teacher activity (Ridwan, 2008). Thus, it can be said that to improve the performance of teachers, there is a need to improve pedagogical competence and motivation of teachers.

Teachers need to understand the learner through learners' characteristics primarily on things related to aspects of intellectual, emotional, moral and background of learners. It is intended to smoothen the process of interaction between learners and teachers so that the learning objectives can be well achieved as expected. In the implementation of learning, teachers identify students ' prior knowledge. This activity aims to determine the ability of early learners who have owned both of the material that has been taught and what will be taught which is done by providing preliminary activities such as apperception and motivation (Hasanuddin \& Cut Nurmaliah, 2010). According to Azzet (2011) Teachers who are able to build the spirit of student participants are able to explain the purpose of the material to be studied and being studied. By knowing the purpose of learning, learners will awaken his consciousness too eager to learn. In addition, every effort should be appreciated by the teacher.

Pedagogical Competence is one type of competencies that absolutely need to be mastered by teachers. Basically, pedagogical competence is the ability of teachers to manage the education of students. Pedagogical competence refers to skills of teachers to deal with three aspects of teaching skills, namely lesson planning, implementing teaching and learning process, and assessing students ${ }^{\text {ee }}$ learning. According to Susilo (2011: 115), pedagogical competence is the ability of teachers to manage the education of students, include: setting up the learning device, implementing the learning, and evaluation. In this section, the researcher only focuses on one aspect of pedagogical competences namely the ability of teachers to implement the learning process that consists of how the teachers manage classroom and use instructional media.

Hightower et al. (2011) claimed that a qualified teacher is a teacher who has a positive effect on student process of learning and development through a combination of content mastery, command of a broad set of pedagogic skills, and communications and interpersonal skills. It is commonly known when the learning objectives did not meet the targeted standard; the teacher will be the one to blame mostly. Indeed, it is not fair because learning is a system or program influenced by many affecting factors mentioned earlier. Nevertheless, the perception toward the teacher's vital role in the success of learning is reasonable as in case there is an insufficient learning facility, we do still have hope if the teacher has standard competence to do so. Conversely, when the facility has been excellent, but the teacher's quality is low, it will not have a significant effect on obtaining learning objectives.

The concept of pedagogic competence also tends to be used with the meaning of the minimum professional standard, often specified by law, which should raise a person in 
fulfilling a particular role of the teaching profession (Gliga, 2002). The emphasis in understanding pedagogical competence should focus on the integrated features which outline the ability to solve educational problems. Therefore, the typical tasks should occur in situations of real pedagogical activities by applying knowledge, professional and life experience, values, and talents in a creative manner to obtain appropriate and effective results. Sampson and Fyrtos (2008) argue that competence has regarded the notion from the perspective of human resource management of vocational training and education, in the attempt to observe the importance of the interdependence between personal characteristics, proficiency level, and context. Richard in (2015) asserted that an excellent pedagogic competence is an aspect of teachers' knowledge and skills. It includes teachers' awareness, classroom management, interaction, teaching language skills such as reading, listening, speaking, writing, grammar and vocabulary, assessing language skills, and using the appropriate approaches, methodologies, techniques, and strategies. If the teacher can master on those criteria, and can also apply them in the classroom, then, it means that the teacher has an excellent pedagogic competence. Another definition by Ryegård (2010) stated about an important thing that all teachers should understand is about students' needs in the classroom. He disputes that learners do not like teachers who spend most of the time lecturing in the classroom. Lecturing time makes the students demotivated because they do not like being passive in class. Consequently, learners have limited input to the learning process. If it happens, the learning process will not run as well as the teacher expected.

Slavík (2008) categorized the teacher's professional competence into five items, they are as follows; a) Mastery a systematic body of knowledge. b) Ability to apply practical experience in the specialization according to the subject of the study. c) Ability to transform the knowledge based on the subject of study. d) Ability to integrate the inter-disciplinary knowledge and create subjectlinks. e) Ability to use the information and communication technology effectively.

When defining the competence concerning understanding of the social world, some authors use the term social competence, others emotional competence. The analysis of both approaches to naming this competence demonstrates that most of the authors refer to the same areas. Social competence is defined as effectiveness in social interaction. Effectiveness is conceptualized as "the outcome of a system of behaviours, organized to meet short- and long-term developmental needs" (Attili, 1990; Waters \& Sroufe, 1983 in Rose-Krasnor, 1997). The effectiveness approach to competence implies that social competence is transactional, that means that it requires interaction between person and the social environment. Second, the nature of social competence is context related. The behaviours depend on the situation. Moreover, social competence is performance-oriented. It refers to the performance in typical interactions, not under ideal conditions. Further, the effectiveness approach stresses that social competence is not a set of predefined behaviours but more complex organizing construct. Finally, social competence is relative to specific goals. It means that the same behaviour may be successful or unsuccessful depending on the goal (Rose-Krasnor, 1997).

A broader definition describes social competence as "involving the personal knowledge and 
skills which persons develop in order to deal effectively with life's numerous choices, challenges and opportunities" (Leffert, et al.; 1997 in Han, Kemple, 2006). Based on this definition, six components of social competence have been distinguished:

- Self-regulation: the capacity to control impulses, resist temptation and pressure, delay gratification, reflect on one's feelings and monitor oneself.

- Interpersonal knowledge and skills enabling to understand other's needs and feelings, to articulate one's own ideas and needs, to cooperate, to negotiate, to solve problems, to express emotions, to understand social situations accurately and to initiate and to maintain friendship.

- Positive self-identity: it includes sense of competence and personal power, sense of self-worth and sense of purpose.

- Cultural competence: the capacity to interact effectively and comfortably with people of varying ethnic and racial backgrounds and to recognize and question unfair treatment of others and to act for social justice.

- Adopting social values such as: encompassing caring, equality, honesty, social justice, responsibility, healthy lifestyles and sexual attitudes and flexibility.

- Planning and decision-making skills: the ability to act in a purposeful way by making choices, developing plans, solving problems and carrying out positive actions to achieve social goals (Han, Kemple, 2006).

Table 1. The overlapping components of social and emotional competence definitions

\begin{tabular}{|c|c|}
\hline $\begin{array}{l}\text { Five crucial emotional competences } \\
\text { presented by Goleman }\end{array}$ & $\begin{array}{c}\text { Components of social competence presented } \\
\text { by Han and Kemple }\end{array}$ \\
\hline Self and other awareness & $\begin{array}{l}\text { Self-regulation - the capacity to reflect on } \\
\text { one's feelings and monitor oneself; } \\
\text { Interpersonal knowledge and skills enabling } \\
\text { to understand other's needs and feelings. }\end{array}$ \\
\hline Mood management & $\begin{array}{l}\text { Self-regulation - the capacity to control } \\
\text { impulses, resist temptation and pressure }\end{array}$ \\
\hline Self-motivation & $\begin{array}{l}\text { Positive self-identity - sense of purpose; } \\
\text { Planning and decision-making skills - the } \\
\text { ability to act in a purposeful way }\end{array}$ \\
\hline Empathy & $\begin{array}{l}\text { Interpersonal knowledge and skills enabling } \\
\text { to understand other's needs and feelings. }\end{array}$ \\
\hline Management of relationships & $\begin{array}{l}\text { Interpersonal knowledge and skills enabling } \\
\text { to initiate and maintain friendship }\end{array}$ \\
\hline
\end{tabular}

The holistic approach in defining social competence is presented in the definition designed by the Research Centre for Experiential Education. Social competence "refers to a differentiated awareness of one's own feelings, motives and behaviour and to the ability to enter into peoples' feelings, perceptions, thoughts and intentions (role taking capacity). It comprises the capacity to intuitively understand interactions, to predict and to anticipate behaviour, taking 
into account the social and cultural context and personal characteristics such as age, and personal traits. In addition to this, social competence requires a broad repertoire of ways to interact with others and the capacity to sense what the most adequate approach is in a certain situation" (Leavers, 2007).

Social competence is the result of 'deep-level-learning'. A teacher should contribute to developmental changes in child's basic schemes concerning social worlds by creating a learning environment in which children can have experiences addressing capacities to understand feelings in themselves and in others. Moreover, education should help children to emphasize with others and to master a repertoire of ways to interact with others. The Experiential Education definition of social competence covers all these elements and therefore, it seems to be the most relevant.A crucial role in developing social competence is played by a teacher. He/she should be able to select tools and materials that contribute in developing social competence in children. A teacher should offer activities dealing with emotions and social interactions. It can be done by a variety of activities such as a circle time during which children can reflect on feelings; reading books and stories which give the possibility to talk about interactions between people and about the motives behind peoples' behaviours; role playing; artistic forms of expression like painting, drawing, modeling that help children to articulate their emotions.

Teaching is not only a cognitive challenge; it is also socially and emotionally demanding (Jennings \& Greenberg, 2009). In order to meet these challenges over extended periods of time, teachers need to regulate their engagement and to develop ways of coping with the constant demands of their work. Empirical research has found that a combination of high engagement and a lack of stress management skills comprise a risk factor for reduced wellbeing and performance (Hobfoll \& Freedy, 1993; Maslach \& Leiter, 1999). Teachers therefore need to develop self-regulation skills in order to maintain their occupational commitment over time and to preclude unfavorable motivational and emotional outcomes. Note that "self-regulation" has a specific meaning in this context. In contrast to the use of the phrase with respect to student learning, "self-regulation" in this context indicates the ability to engage oneself while simultaneously monitoring one's own behavior and, in stressful situations, finding ways to cope adaptively (Klusmann, et al., 2008).

The way that teachers display positive and negative emotions in the classroom provides a model for young students (Denham, et al., 2007; Denham, Bassett, \& Zinsser 2012; FigueroaSánchez, 2008; Jennings \& Greenberg, 2009; Jones et al., 2013; Macklem, 2008a; McCabe \& Altamura, 2011; Schonert-Reichl, 2011; Yoder, 2014; Zinsser et al., in press). Modeling teaches students about social norms for conveying and regulating emotions, and it helps students understand and regulate their own emotions. Throughout the day, teachers can effectively display social and emotional competence in the classroom by modeling: • Genuine, appropriate emotions and responses to emotions (for example, remaining evenkeeled in response to a student's angry outburst). - Emotion language and ways to communicate feelings to others ("I'm so excited, happy, nervous"). - Techniques for effective social interaction (for example, active listening and offering help). - Strategies for emotional and behavioral self-regulation and problem solving (box 3). 
Teachers can choose how to react to students' expressions of emotions. Harsh, punitive, or dismissive responses can have negative effects on students' social and emotional competence. Conversely, reacting to student emotions (especially negative emotions like sadness or anger) with empathy and warm, nonjudgmental support, as well as coaching students through their emotions, promotes understanding of their emotions, self-regulation, and competence (Denham et al., 2012; Domitrovich et al., 2012). The following ways of reacting to young students' emotions have been shown to promote social and emotional learning (Jones et al., 2013; Macklem, 2008b; Zinsser et al., in press): - Encouraging the expression of emotions, positive or negative, when they arise. - Reading and matching individual students' temperaments and emotions. - Acting as a "sportscaster" or interpreter during student disputes by describing the situation. - Responding empathetically to students who have meltdowns or who become flooded with emotion. - Practicing reflective listening and using calming scripts to help students regain control. - Engaging in "interpersonal scaffolding" (Kemple \& Ellis, 2009) or "social problem-solving dialogue" (Denham \& Burton, 2003) during conflicts. These approaches involve guiding and encouraging each student who is involved in the situation to voice his or her perspective, generate potential solutions, and jointly decide on and implement a mutually acceptable solution. • Using emotion coaching (box 4).

Motion coaching is a popular term in parenting literature. It includes: - Attending to and respecting the emotions exhibited by the student. - Direct teaching of self-soothing and calming down. - Showing interest in how the student feels. - Modeling and talking about remaining engaged with others when the situation is stressful. $\bullet$ Pointing out what caused the emotion. - Answering the student's question. A teacher's social and emotional awareness and sensitivity contribute to a positive emotional climate in the classroom (Denham et al., 2012; Jennings \& Greenberg, 2009; Jones et al., 2013; Zinsser et al., in press). Teachers who are knowledgeable about their own emotions may be better able to empathize with a student's complex emotional reactions. Teachers who can regulate their own emotions may be more adept at creating a consistent emotional environment. Moreover, teachers who succeed in managing their feelings may respond more effectively to challenging situations with students (Zinsser et al., in press). The effects of teacher social and emotional competence on student outcomes are shown in box 6 . And is specifically helping the student manage anxiety, sadness, and anger.

Ways to promote teachers' emotional skills include direct training, reflective supervision and relationship-building, and stress-reduction techniques. - Teacher training. Training can increase teachers' awareness of their role in students' social and emotional learning. It can help them become more willing to show emotions, remain emotionally positive in the classroom, and modulate their negative emotions. Training can also give new teachers specific strategies to use in reacting to students' negative feelings (Denham et al., 2012). • Reflective supervision and relationship-building. Regular meetings with a supportive supervisor that focus on the experiences, thoughts, and feelings directly connected with teaching can help teachers step back from day-to-day stresses, access and understand their emotions, and problem-solve more effectively (Denham et al., 2012; Jones et al., 2013). • Stress reduction techniques. Teachers can learn techniques to improve their social and 
emotional competence. If the factors that cause stress cannot be mitigated, several techniques can help. Young students develop social and emotional skills by interacting with others. Since many students spend substantial time in school, research has started to examine the ways that a teacher's own social and emotional skills can affect students' success in school (Denham et al., 2012). Research reveals that teachers' social and emotional competence influences the quality of teacher-student relationships, classroom organization and management, and teachers' modeling of social and emotional skills for students (Jones et al., 2013).

For social competence development, it is also very important how children experience the conditions offered by a teacher. According to Experiential Education, there are two indicators that inform what the quality of children's experience is: well-being and involvement (Laevers, 1998). Well-being occurs when children feel at ease, act spontaneously, are open to the world, express inner rest and relaxation, show vitality and self-confidence, enjoy life and are in touch with their feelings and emotions. Involvement is the process variable that refers to the child's activity. It is an intense mental activity characterised by extreme concentration and persistence, a high level of motivation and openness to stimuli. The satisfaction is determined by the exploratory drive and the individual pattern of developmental needs. Moreover, involvement occurs when the activity is situated in child's zone of proximal development.

The Experiential Education suggests five factors that influence involvement and well-being:

1. Group Climate and Relationships - the designed activity affects the class climate and the relationship between children;

2. The Degree of Adaptation to the Developmental Level - the activity takes place in the zone of proximal development that means it is not too easy and too difficult;

3. The Degree of Child Activity - activating work forms are employed, the work activates each child;

4. Closeness to Reality - the content is enriched by a concrete material, by lively presented information;

5. Room for Child Initiative - the child has an opportunity to make personal choices (Laevers, 2007).

However, these five factors do not guarantee impact, since development of competencies depend to the large extent on the teacher.

Personality consists of stable characteristics which explains why a person behaves in a particular way (Mullins, 2005). According to Hogan (1991), a person personality is a relatively stable precursor of behavior; it underlies an enduring style of thinking, feeling and acting. However, Guthrie et. al (1998) stated that personality can be defined as a predisposition to act or behave in a characteristic fashion in response to one's environment. Based on Pervin et. al (2005), personality refers to the characteristics of the person that account for consistent patterns of feeling, thinking and behaving. In contrast to other competencies, personal competence according to Joni, (2008) needs special attention, because most of the personality is not formed through direct learning in the context of formal 
education, but most are formed as a result of accumulated escort learning experience gained on preposition and previous education are formed even in a family environment.

Due to the need of improving the teaching profession, this study focuses on how teacher's personality may influence their teaching effectiveness in realizing all these agenda. By understanding the relationship between personality of teacher and teaching effectiveness, it would help to identify which personality that influence their teaching effectiveness, so that they may use or select the best teaching method that suits their personality to make their teaching become more effective. It is because of the effective teaching also dependent on how the teacher selects the teaching method. As stated by Fauziah et. al (2005), it is important to select appropriate teaching methods because these determine the effectiveness and quality of teaching. It means that the suitability between personality and teaching method selection will lead to the achievement of teaching effectiveness. All these elements are important in order to make the objective of a lesson to be successfully implemented.

According to Magno and Sembrano (2008), teacher performance includes measures of general teaching practices such as teaching methods and strategies, classroom management, planning and organization of teaching. It means that personality could be a predictor of job performance as well as for teaching effectiveness. As stated by Curtis and Liying (2001), teacher performance is influenced by the teachers' personality characteristics. May and Lam (2004) stated a certain personality constructs (The Big Five Personality factors) have repeatedly shown, in meta-analysis studies, to be valid predictors of job performance. Barrick and Mount (1990) mentioned that a great deal of published research selection has been geared towards understanding the relationship between personality constructs and job performance. Salgado (1997) stated that a number of meta-analytic studies have demonstrated the predictive validity of the FFM (Five Factor Model) in occupational settings. This is bringing a number of researchers to propose a moratorium on meta-analyses on the relationship among the FFM and job performance criteria. Therefore, by understanding personality and the job performance which is related to the how the teachers conduct their job especially in teaching, it would help to the understanding of how the teacher's personality influence teaching effectiveness.

However, the other personality traits that have relationship with job performance are openness and agreeableness. As stated by Salgado (1997) which confirmed many of the relationships between the Big Five factors and various job performance criteria and found openness and agreeableness to valid predictors of training proficiency. Based on Thoreson et. al (2003), they found significant tru-score correlations between work attitudes and dispositions and personality traits. According to Centra (1998), the measures for performance are interpreted as levels where teachers achieved to a certain degree the criteria specified. The criterion is focus on teaching method. As stated by Magno and Sembrano (2008), teacher performance includes measures of general teaching practices such as teaching methods and strategies, classroom management, planning and organization of teaching. Curtis and Liying (2000), stated that teacher performance is influenced by teachers' personality characteristics. It means that the personality had an effect on teaching practices as well as teaching 
effectiveness. Muray et. al (1990), stated that there are numerous studies showing that personality is a significant predictor of effective teaching.

Magno and Sembrano (2008), mentioned that personality plays a role in the way teachers are rated on their being effective in teaching. In terms of personality characteristics that influence the teaching effectiveness, Young and Shaw (1999) explained that the behavior attributed to good teaching coincides with certain personal characteristics such as being friendly, approachable, warm, kind, appreciative and inspiring. While Magno and Sembrano (2008) stated that the content of teacher effectiveness includes some aspects of teachers' personality that are being tolerant, having a good sense of humor, being warm and friendly and being concerned about students. In a recent study by Yeh (2006), it was suggested that personality types such as intrapersonal intelligence, critical thinking dispositions and judicial thinking style results in a more reliable outcome in reflective teaching and mastery performance. Based on the above review, therefore it shows that there is relationship between personality and teaching effectiveness.

Aziz (2003) stated that there are several factors that affect personality development which led to the personality differences and it will influence the attitude and behavior related to work. Based on the above model, the factors affecting personality development is not included because the study is focused on personality differences or personality dimensions that influence the attitude and behavior. Mullins (2005), state that personality consists of stable characteristics which explain why a person behaves in a particular way. In this study, personality dimension focus on the personality of teacher while the behavior related to work could be considered as behavior of teaching which focus is on teaching effectiveness.

\section{Research Methodology}

This study employs the survey research design. The population of this study comprises of all the students of all the secondary schools that are currently functioning in Buea municipality. These include all the public, denominational and lay educational secondary institutions in Buea municipality. The target population of this study was made up of 5,992 consisting of all the students in the six targeted secondary schools that where selected using stratified sampling technique. The accessible population of this study was made up of 703 students consists of form four students of all the targeted schools. The accessible population was determined using convenient sampling technique. The sample size of this study is made up of 300 students drawn from the accessible population. This sample size was determined using simple random sampling technique. while was used to select the accessible population. Questionnaire was used as the instrument for data collection. Closed ended, structured questions of the Likert-scale type, consisting of four scale response options was used. Validity of the instrument was assured by giving sample copies to the test and measurement experts and to an educational psychologist to review them for face, content, construct, and criterion validity. To ensure reliability of the questionnaire, the instrument was pilot tested in a school not included in the study. Their responses were subjected to Cronbach's Alpha Coefficient reliability test which yield a value of 0.713 . 
The researcher personally administered the questionnaire to all the students. The researcher informed the administrators of the respective schools about his intension to carry out a study with the teachers of their schools. A suitable time for administering the instrument was negotiated with the head teachers. The researcher administered the questionnaire on face-toface bases and collect immediately the students finish answering them. To ensure anonymity and honest responses, they students were not allowed to write their names or anything that can identify them on the questionnaire sheet. Data collected were analyzed using Pearson product moment correlation coefficient.

\section{Research Hypotheses}

This study was based on the following hypotheses; The first null hypothesis states that there is no significant relationship between teachers' pedagogic competence and students learning in some secondary schools in Buea Municipality while the alternative hypothesis states that there a significant relationship between teachers' pedagogic competence and students learning in some secondary schools in Buea Municipality. The second null states that there is no significant relationship between teachers' professional competence and students' learning in some secondary schools in Buea Municipality while the alternative hypothesis states that there a significant relationship between teachers' professional competence and students' learning in some secondary schools in Buea Municipality. The third null hypothesis states that there is no significant relationship between teachers' socio-emotional competence and students learning in some secondary schools in Buea Municipality while the alternative hypothesis states that there a significant relationship between teachers' socio-emotional and students learning in some secondary schools in Buea Municipality. The fourth null states that there is no significant relationship between teachers' personality competence and students' learning in some secondary schools in Buea Municipality while the alternative hypothesis states that there a significant relationship between teachers' personality competence and students' learning in some secondary schools in Buea Municipality.

\section{Analysis and Results}

Pearson Product Moment Correlation analysis of the influence of teachers' competence on students' learning in some secondary schools in Buea municipality. ( $N=300$ and at 0.05 level of significance).

Table 1: Influence of teachers' pedagogic competence on students' learning

\begin{tabular}{|c|c|c|c|c|c|}
\hline Variable & $\sum X$ & $\sum \mathrm{X}^{2}$ & & & \\
\hline & $\sum \mathrm{Y}$ & $\sum \mathrm{Y}^{2}$ & $\sum X Y$ & $\Gamma_{\mathrm{xy}}$ & $\mathrm{p}$-value \\
\hline $\begin{array}{l}\text { Teachers' pedagogic competence } \\
\text { (X) }\end{array}$ & 1616 & 26666 & 27268 & $0.762 *$ & 0.001 \\
\hline Students learning (Y) & 1740 & 30772 & & & \\
\hline
\end{tabular}

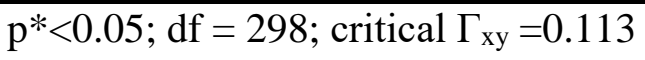


The result of the analysis reveals that the calculated $\Gamma_{\mathrm{xy}}$-value of 0.762 is higher than the critical $\Gamma_{\mathrm{xy}}$-value of 0.113 at .05 level of significance with 298 degrees of freedom. Also, the p-value of 0.001 is lower than 0.05 . With the result of this analysis, the null hypothesis was rejected and the alternative hypothesis retained. This result therefore means that there is a significant relationship between teachers' pedagogic competence and students learning. A further exploration of the effect showed that the $\Gamma_{\mathrm{xy}}=0.762$ was positive. This indicates that the better teachers' pedagogic competence the more students' learning in secondary schools in the Buea Municipality.

Table 2: Influence of teachers' professional competence on students' learning

\begin{tabular}{|c|c|c|c|c|c|}
\hline Variable & $\sum \mathrm{X}$ & $\sum \mathrm{X}^{2}$ & & & \\
\hline & $\sum \mathrm{Y}$ & $\sum \mathrm{Y}^{2}$ & $\sum X Y$ & $\Gamma_{\mathrm{xy}}$ & p-value \\
\hline Teachers' competence $(\mathrm{X})$ & 1616 & 26666 & 27268 & $0.734 *$ & 0.001 \\
\hline Students; learning (Y) & 1740 & 30772 & & & \\
\hline
\end{tabular}

$\mathrm{p}^{*}<0.05 ; \mathrm{df}=298 ;$ critical $\Gamma_{\mathrm{xy}}=0.113$

The result of the analysis reveals that the calculated $\Gamma_{\mathrm{xy}}$-value of 0.734 is higher than the critical $\Gamma_{x y}$-value of 0.113 at .05 level of significance with 298 degrees of freedom. Also, the p-value of 0.001 is lower than 0.05 . With the result of this analysis, the null hypothesis was rejected and the alternative hypothesis retained. This result therefore means that there is a significant relationship between teachers' professional competence and students learning. A further exploration of the effect showed that the $\Gamma_{\mathrm{xy}}=0.734$ was positive. This indicates that positive teachers' professional competence leads to mores students learning in secondary schools in the Buea Municipality.

Table 3: Influence of teachers' socio-emotional competence on students' learning

\begin{tabular}{llllll}
\hline Variable & $\sum \mathrm{X}$ & $\sum \mathrm{X}^{2}$ & & & \\
& $\sum \mathrm{Y}$ & $\sum \mathrm{Y}^{2}$ & $\sum \mathrm{XY}$ & $\Gamma_{\mathrm{xy}}$ & p-value \\
teachers' socio-emotional competence & 1700 & 29072 & 28579 & $0.236^{*}$ & 0.001 \\
$(\mathrm{X})$ & & & & & \\
students' learning (Y) & 1740 & 30772 & & & \\
\hline
\end{tabular}

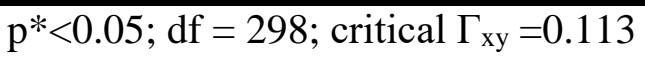

The result of the analysis reveals that the calculated $\Gamma_{\mathrm{xy}}$-value of 0.236 is higher than the critical $\Gamma_{\mathrm{xy}}$-value of 0.113 at .05 level of significance with 298 degrees of freedom. Also, the p-value of 0.001 is lower than 0.05 . With the result of this analysis, the null hypothesis was rejected and the alternative hypothesis retained. This result therefore means that there is a significant relationship between teachers' socio-emotional competence and students learning. A further exploration of the effect showed that the $\Gamma_{\mathrm{xy}}=0.236$ was positive. This indicates that the better teachers' socio-emotional competence the more students' learning in secondary schools in the Buea Municipality. 
Table 4: Influence of teachers' personality competence on students' learning

\begin{tabular}{|c|c|c|c|c|c|}
\hline Variable & $\sum \mathrm{X}$ & $\sum X^{2}$ & & & \\
\hline & $\sum \mathrm{Y}$ & $\sum \mathrm{Y}^{2}$ & $\sum X Y$ & $\Gamma_{\mathrm{xy}}$ & $\mathrm{p}$-value \\
\hline $\begin{array}{l}\text { Teachers' personality competence } \\
\text { (X) }\end{array}$ & 1688 & 28898 & 28820 & $0.458^{*}$ & 0.001 \\
\hline Students learning $(\mathrm{Y})$ & 1740 & 30772 & & & \\
\hline
\end{tabular}
$\mathrm{p}^{*}<0.05 ; \mathrm{df}=298 ;$ critical $\Gamma_{\mathrm{xy}}=0.113$

The result of the analysis reveals that the calculated $\Gamma_{\mathrm{xy}}$-value of 0.458 is higher than the critical $\Gamma_{\mathrm{xy}}$-value of 0.113 at 0.05 level of significance with 298 degrees of freedom. Also, the p-value of 0.001 is lower than 0.05 . With the result of this analysis, the null hypothesis was rejected and the alternative hypothesis retained. This result therefore means that there is a significant relationship between teachers' personality competence and students learning. A further exploration of the effect showed that the $\Gamma_{\mathrm{xy}}=0.458$ was positive. This indicates that positive teachers' personality competence leads to mores students learning in secondary schools in the Buea Municipality.

\section{Conclusion}

The calculated Pearson product moment correlation coefficient was higher than the critical value for all the four hypotheses. Also, the p-value of 0.001 was lower than 0.05 alpha level of significance. This led the researcher to reject all the null hypotheses and retained the alternative hypotheses at 0.05 level of significance. The table of each teacher competence (pedagogical competence, professional competence, social -emotional competence and personality competence) as applied to the teaching and learning process show that each has a positive effect on students learning. This means that teacher competencies are needed, especially in the learning process, not only one competency that must be mastered, but all four competencies. In addition, each teacher's competence has an influence on student learning outcomes. According to Annisa (2020), the higher each competency possessed by the teacher, the higher the learning outcomes obtained by students. Therefore, teacher competence is needed in the learning process in order to improve learning outcomes.

These findings are also supported by Ma'rifatullah et.al., (2019) who said that, teachers are the spearhead of success in shaping the nation's next generation of quality; it seems to have high professional skills and attitudes, so it can work earnestly in educating their students to be qualified. Also, according to Rusmini (2018), through professional treatment, it is hoped that a learning process will occur in students. Thus, teacher teaching outcomes are determined by the level of student learning outcomes. The higher the student learning outcomes, the better the results of teaching the teacher4. As a result, the teaching and learning process between teachers and students can run well and because learning goals to be achieved. As one component in the learning process, the teacher has a position that determines the success of learning, because the teacher's main function is to design, manage, and evaluate learning. The teacher is in charge of transferring a set of organized knowledge so that knowledge becomes 
part of the student's knowledge system. Therefore, the teacher plays an important role in the teaching and learning process to create effective and innovative learning and to arrange the class so that students are active, creative and pay attention to the class when learning (Sequeira,2012).

As a profession, all teachers should have pedagogical competence, personality competence, professional competence and social competence. Pedagogical competence is the ability in the management of students that includes an understanding of the student, designing and conducting learning, evaluation of learning outcomes, and the development of student to actualize various potentials. Personal competence is personal abilities that reflect the personality steady, stable, mature, wise and dignified, become role models for students, and noble (Nabila, 2016).

\section{Recommendations}

From the findings of the study the following recommendations are proffered; teachers should partake in all seminars/workshops if possible, because they will help to improve on their teaching competence, Educational administrators should equip the regional pedagogic inspectors with sufficient pedagogic didactic materials that they can use to train or carry out in-service training for the teachers doing seminars/workshops, principals should encourage mentor-mentee relationship among teachers of the same department, because this will help train the novice teachers on all the aspects of competence and lastly, the decision-makers should recruit more trained teachers so as to reduce teacher-student ratio. This is very important because, teacher competence can only be effective in a classroom that meets international standard of teacher-student ratio.

\section{References}

1) Alexander, P. A. (2008). Charting the course for the teaching profession: The energizing and sustaining role of motivational forces. Learning and Instruction, 18, 483-491. doi: 10.1016/j.learninstruc.2008.06.006

2) Annisa, N (2020). An analysis of teacher competence on teaching learning process of English at smait iqra' kota Bengkulu. Thesis Submitted as A Partial Requirements for the Degree of Sarjana (S. Pd) in Study Program of English Education.

3) Bransford, J., Derry, S., Berliner, D., \& Hammerness, K. (2005). Theories of learning and their roles in teaching. In: L. Darling-Hammond, J. Bransford, P. LePage, K. Hammerness, \& H. Duffy (Eds.), Preparing teachers for a changing world: What teachers should learn and be able to do (pp. 40-87). San Francisco, CA: Jossey-Bass.

4) Ciarrochi, J., Scott, G., Deane, F., Heaven, P. (2003). Relations between social and emotional competence and mental health: a construct validation study. Personality and Individual Differences, 35, 1047-1963.

5) Desimone, L.M. (2009). Improving impact studies of teachers' professional development: Towards better conceptualizations and measures. Educational Researcher, 38(3), 181-199. 
6) Epstein, R. M., \& Hundert, E. M. (2002). Defining and assessing professional competence. JAMA: Journal of the American Medical Association, 287, 226 -235. doi:10.1001/jama.287.2.226

7) Frenzel, A. C., Goetz, T., Lüdtke, O., Pekrun, R., \& Sutton, R. E. (2009). Emotional transmission in the classroom: Exploring the relationship between teacher and student enjoyment. Journal of Educational Psychology, 101, 705-716. doi:10.1037/a0014695

8) Garet, M.S., Porter, A., Desimone, L., Birman, B.F., \& Suk Yoon, K. (2001). What makes professional development effective? Results from a national sample of teachers. American Educational Research Journal, 38(4), 915-945.

9) Gay, L.R., et al. (2006). Educational Research. Pearson: Merrill Prentice Hall.

10) Goodman, G., Arbona, C., \& Dominguez de Rameriz, R. (2008). Highstakes, minimum- competency exams: How competent are they for evaluating teacher competence? Journal of Teacher Education, 59, $24 \quad-39$. doi:10.1177/0022487107309972

11) Hayes, C. (2003). Teacher Professional Development: A Primer for Parents and Community Members.

12) Jones, S. M., Bailey, R., \& Jacob, R. (2014). Social-emotional learning is essential to classroom management. Phi Delta Kappan, 96(2), 19-24.

13) Jones, S. M., Bouffard, S. M., \& Weissbourd, R. (2013). Educators' social and emotional learning skills vital to learning. Phi Delta Kappan, 94(8), 62-65.

14) Julkifli Hidayat Ada (2016). The Contribution of Teachers' Pedagogical Competence Toward the Effectiveness of Teaching of English At Mtsn Balang-Balang. Volume 02, Number 02

15) Katane, Irena et al. "Teacher competence and further education as priorities for sustainable development of rural school in Latvia." Journal of Teacher Education and Training. 6. 2006.

16) Katane, Irena et al. "Teacher competence and further education as priorities for sustainable development of rural school in Latvia." Journal of Teacher Education and Training. 6. 2006:41-59.

17) Kemple, K. M., \& Ellis, S. M. (2009). Peer-related social competence in early childhood: Supporting interaction and relationships. In E. L. Essa \& M. M. Burnham (Eds.), informing our practice: Useful research on young children's development (pp. 5-12). Washington, DC: National Association for the Education of Young Children. http://eric.ed.gov/?id=ED505533

18) Kuijpers, J.M., Houtveen, A.A.M., \& Wubbels, T. (2010). An integrated professional development model for effective teaching. Teaching and Teacher Education, 26, $1687-1694$

19) Laevers, F., Cuvelier, N. (ed.) (2004). A House Full of Emotions. All About Feelings and Relationships. A case and manual. CEGO-Publishers.

20) Laevers, F., Vandenbussche, E., Kog, M., Depondt, L. (1997). A process-oriented child monitoring system for young children. Leuven: Centre for Experiential Education. 
21) Livia, T. (2010). Teachers ${ }^{\text {ee }}$ thought of their academic background and professional development. Unpublished M. A. Thesis, Atma Jaya Catholic University of Indonesia, Jakarta.

22) Livia, T. (2010). Teacherse thought of their academic background and professional development. Unpublished M. A. Thesis, Atma Jaya Catholic University of Indonesia, Jakarta.

23) Lortie, D. C. (1975). School teacher: A sociological study. Chicago, IL: The University of Chicago Press.

24) Ma'rifatullah, Andi Tenri Ampa\&Awalia Azis (2019). Teachers' Pedagogic Competence in Teaching English at Sman 1 Sanggar Bima. Exposure Journal 91. Vol. 8 No. 1 .

25) Macklem, G. L. (2008a). Emotion regulation in the classroom. In G. L. Macklem (Ed.), Practitioner's guide to emotion regulation in school-aged children (pp. 63-81). New York, NY: Springer Science + Business Media.

26) McCabe, P. C., \& Altamura, M. (2011). Empirically valid strategies to improve social and emotional competence of preschool children. Psychology in the Schools, 48(5), 513-540.

27) Nabila, Haniati. (2016). The Influence of Pedagogic Competence and Professional Competence to Performance of Teachers Social Studies in Trowulan District. International Conference on Ethics of Business, Economics, and Social Science, p. 560-561

28) Oser, F. K., Achtenhagen, F., \& Renold, U. (Eds.). (2006). Competence oriented teacher training. Old research demands and new pathways. Rotterdam, the Netherlands: Sense

29) Penuel, W.R., Fishman, B.J., Yamaguchi, R., \& Gallagher, L.P. (2007). What makes professional development effective? Strategies that foster curriculum implementation. American Educational Research Journal, 44(4), 921-958.

30) Pintrich, P. R. (2003). A motivational science perspective on the role of student motivation in learning and teaching contexts. Journal of Educational Psychology, 95, 667-686. doi:10.1037/0022-0663.95.4.667

31) Richards, Jack C. (2011). Competence and Performance in Language Teaching. New York: Cambridge University Press.

32) Richardson, V. (1996). The role of attitudes and beliefs in learning to teach. In J. Sikula, T. Buttery, \& E. Guyton (Eds.), Handbook of research on teacher education (2nd ed., pp. 102-106). New York, NY: Macmillan

33) Rose-Krasnor, L. (1997). The nature of social competence: A theoretical review. Social Development, 6 (1) 111-135.

34) Rusmini, Euis. (2018). Pedagogical Competence of Teachers of Social Science Education at Smpn 2 Sidomulyo. Jurnal Studi Sosial, No 1. P. 1-3

35) Sequeira, A. H. (2012). Introduction to Concepts of Teaching and Learning. Article In Ssrn Electronic Journal. P. 1-3

36) Staub, F. C., \& Stern, E. (2002). The nature of teachers' pedagogical content beliefs matters for students' achievement gains: Quasi experimental evidence from 
elementary mathematics. Journal of Educational Psychology, 94, $344-355$. doi:10.1037/0022-0663.94.2.344

37) Timperley, H., Wilson, A., Barrar, H., \& Fung, I. (2007). Teacher professional learning and development. Wellington: Ministry of Education

38) Usman, Moh. Uzer. (1994). Menjadi Guru Professional. Bandung. PT Remaja Rosdakarya

39) Wiwi (2016). An Analysis of Teachers' Pedagogical Competence in Teaching English for Young Learners at Nara Syekh Nurjati State Islamic Institute, Cirebon. An unpublished Thesis. 